\title{
Repræsentation og flerrepræsentation i computermediet og i de levende billeder
}

\author{
Af Lennard Højbjerg
}

\begin{abstract}
Artiklen beskeftiger sig med sporgsmålet om, hvordan computeren representerer andre medier, og hvad man skal forstå ved representation, når computeren benyttes til at vise levende billeder. Centralt $i$ diskussionen stär begrebet flerrepresentation, som belyses med udgangspunkt i en rakke filmteoretiske overvejelser og med inddragelse af eksempler fra sävel gamle som nye medier.
\end{abstract}

Det er en meget udbredt opfattelse, at computermediet er det medie, der som det eneste kan indeholde alle andre medier, samtidig med at computeren indgår i produktionen af snart sagt alle andre medier. Spørgsmålet er, om denne platform blot er en gennemsigtig form, der teknologisk muliggør de andre mediers fremtræden med deres respektive udtrykssubstantielle træk, eller om der i transformationen fra f.eks. film og tv til computermedie sker ændringer i den originale repræsentation i kraft af computermediets egen repræsentation?

Hensigten med denne artikel er at besvare dette spørgsmål og i den forbindelse med fokus på det audiovisuelle at undersøge sammenhængen mellem repræsentation og de tekstuelle træk, der ligger i og omkring repræsentationen.

\section{Reprasentation og binaritet}

I artiklen »Computeren - et medie for en ny skriftteknologisk revolution«(1998), som er en slags abstract af en række andre arbejder med computermediet som emne, analyserer Niels Ole Finnemann computeren og dens integration af næsten alle andre medier.

Når noget sådan kan lade sig gøre på en og samme mediemæssige platform, må det hænge sammen med dette medies helt særlige tekstuelle forhold. Derfor gør Finnemann meget ud af analysen af de computermedie-tekstlige forhold, der muliggør repræsentationen af andre tekster i computeren.

Computeren er ikke en regnemaskine (hvad mange har opfattet den som), ikke et program, ikke et redskab (computeren har flere formål). Den er derimod defineret ved, at det indhold, der behandles, skal foreligge i (s. 44):

- et mekanisk virksomt alfabet

- der styres med en algoritmisk syntaks

- via et interface, der bestemmer syntaksens semantik.

Alfabetet er de binære enheder /0/ og /1/, der i forskellige sekvenser læses af algoritmer (syntaksen), og som bliver til et skærmudtryk i kraft af en interface mellem det algoritmiske niveau og skærmen. Når vi som modtager ser f.eks. skrivebordets skraldespand, er det et skærmudtryk, som er bestemt af en interface mellem dette udtryk og en række algoritmer, der igen læser en (principielt uendelig lang) rækkefølge af /0/'er og /1/'er.

Denne fleksibilitet giver computeren mulighed for at indeholde alle andre medieudtryk, fordi den ikke i sin fremstilling på skærmen er bundet til en fysisk invariant struktur, som det er tilfældet med de fleste andre medier (s. 47):

Computeren er anderledes end alle andre maskiner, fordi dens warkitektur er symbolsk defineret og variable og ikke indbygget i den fysiske invariante struktur.«

Det, Finnemann mener med »... den fysisk invariante struktur«, er for eksempel, at filmens bevægelse baserer sig på en bestemt træghed i det menneskelige øjes perception, som så udløses af fremviserapparaturets kombination af fremførelseshastighed (24 frames per sekund) og den todelte blænde i filmprojektoren, der yderligere skaber 48 sorte frames ( 2 pr. egentlig filmframe). Det menneskelige øje ser faktisk 72 billeder i sekundet $-2 / 3$ af dem 
er sorte - hvert billede står stille i præcis 1/72 sekund og bevæges så videre. Det er denne fysiske arkitektur, som muliggør publikums oplevelse af bevægelse på lærredet. Tilsvarende findes der for tv en række forhold, der skaber betingelsen for oplevelsen af levende billeder. Det er denne fysisk invariante arkitektur, der adskiller de »gamle« medier fra computeren.

Det virksomme binære alfabet med den algoritmiske syntaks er på ingen måde afhængig af, hvilken computer der er tale om, dens ydeevne eller noget som helst andet. Med det binære alfabet og syntaksen, som kan varieres i det uendelige, kan der - via interfacen-skabes de visuelle repræsentationer på computerskærmen, som indgår i denne eller hin konkrete brug. Alfabetet og syntaksen er ikke bundet til den visuelle fremtrædelsesform, der er nødvendig på skærmen. Hvert program kan have sin egen algoritmiske læsning af binære sekvenser, men alligevel se ens ud på skærmen.

Det interessante er derfor, som Finnemann påpeger, at computeren indeholder andre mediers fysisk invariante struktur i symbolsk form, f.eks. viskelæderet, blyanten og skraldespanden. Derfor kan dette »skriftsprog«, som Finnemann kalder det, indeholde alle disse symbolske ikke-skriftlige udtryk. Samtidig betyder det, at der ikke er nogen invariant grænse mellem computerens fysiske struktur og det vidensindhold, der repræsenteres.

\section{Skriftliggørelsen af den visuelle reprasentation}

Finnemann har med pointen om computerens basale skriftsprog også draget nogle mediehistoriske konsekvenser (s. 55):

Det er altså ikke mærkeligt, at mange har været tilbøjelige til at medtage computeren blandt de medier, der bidrager til denne ekspansion af billedforbruget, og slået sammen med de analoge elektroniske medier i en modstilling til den gamle skriftkultur. Det er ikke mærkeligt, men det er forkert.

Alle de forskellige billeder på computerskærmene har måske ikke umiddelbart noget til fælles, men dog dette, at de er dannet på baggrund af en skriftlig repræsentation, som foreligger i et alfabet baseret på to tegn (s. 55):

Vi har således med computeren for første gang i historien fået et medie, hvori den visuelle, billed- lige repræsentation er baseret på en skriftlig - og altså også en sekventiel - repræsentation.

Det er derfor berettiget at se det digitaliserede visuelle billede som erobret af skriftkulturen. Finnemanns påstand er, at det er en ny skriftteknologi, der har erobret billedkulturen, og at den visuelle repræsentation er blevet skriftliggjort. Men samtidig har han introduceret to forskellige repræsentationsbegreber.

For det første er forskellige medieudtryk så som tv, film, bøger, fotografier og malerier representeret $\mathrm{i}$ computeren i og med, at vi som brugere er i stand til at genkende dem på computerens skærm. Ellers ville vi ikke være i stand til at genkende dem som netop film, tv, fotografi, maleri osv. De fremstår i deres synlighed på computerskærmen, så modtageren kan identificere dem som hhv. film, tv, maleri, dvs. at deres oprindelige repræsentationsform genkendes. Dette er den ene form for repræsentation. Men Finnemann skriver også (s. 49):

.... alle de vidensformer og medier, vi har fået til rådighed gennem de foregående 4-500 år i et og samme alfabet, dvs. repræsenteret som tekst.

Det indebærer, at der ikke blot arbejdes med et repræsentationsbegreb, som vedrører de andre mediers synlighed på computerens skærm, men også med en anden form for repræsentation, hvor alle disse medier er repræsenteret dybt nede i computerens basale kodificeringsfunktion i form af det binære alfabet og den algoritmiske syntaks.

Dette er det nye skriftsprog, der samtidig giver en betragtelig udvidelse af vores muligheder for billedbehandling. Det giver os en lang række manipulationsmuligheder med diverse medieudtryk, som ikke fandtes i de analoge medier. Man kan bytte rundt på scener og sekvenser, når man redigerer video blot ved at klikke med musen. Man kan ændre det enkelte billedforløbs syntaks, og tilsvarende kan man farvefiltrere, pixellere og lægge lag på lag af forskellige udtryk oven på hinanden.

Ud over disse praktiske aspekter af computermediets indoptagelse af andre medier er der hermed sat fokus på, hvad der egentlig menes med, at et medie repræsenterer et eller andet.

\section{Repræsentationsbegrebet}

I filosofien har man brugt begrebet repræsentation om det, at en idé, en tanke, et billede, et tegn, et sprog- 
ligt udtryk står for noget andet end sig selv. For eksempel illustrerer sætningen: »tanken repræsenterer en holdning jeg slet ikke .... den almene brug af repræsentationsbegrebet. Repræsentationsbegrebet omfatter, at noget andet end det objekt, der repræsenteres, er et medie for repræsentationen.

I den kunsthistoriske tradition har det altid være på dagsordenen at diskutere forskellen mellem det kunstneriske udtryk (kunstnerens personlige eller periodeprægede stil) og kunstværkets repræsentation, det, der blev gengivet på lærredet eller i f.eks. skulpturens sten. Denne diskussion er klarest sammenfattet af Gombrich i Art and Illusion - The Psychology of Pictorial Representation og John Willats i Art and Representation (1997). Og tilsvarende har filmteorien beskæftiget sig med, hvordan billedliggørelsen i levende billeder »ligner« eller mere filosofisk - repræsenterer, det objekt, der forestilles. Inden for computermedieområdet er det som nævnt Niels Ole Finnemann, der har beskæftiget sig med problemstillingen.

Et andet spørgsmål, som Finnemann har behandlet, er, om den skriftliggørelse af den visuelle repræsentation, som tilsyneladende finder sted i computermediet, også definitivt ændrer på den visuelle repræsentation, som disse medier oprindeligt havde. Da jeg her primært skriver om billeder og levende billeder i computeren, vil jeg i det følgende se på, hvorledes repræsentationsbegrebet er blevet diskuteret i en filmteoretisk kontekst.

De levende billeders repræsentationssystem er beskrevet af flere skribenter inden for de sidste årtier. Roland Barthes tager hul på debatten i artiklen »Brecht, Diderot, Eisenstein« (1974), hvor han opridser den visuelle repræsentations basale karakter. Det, som er repræsenteret, er repræsenteret, fordi det kan ses, dvs. indrammet. Rammen - »the frame« - sætter det, der er, men repræsentation er mere, mener Barthes, end blot den direkte (men afgrænsede) imitation. For så længe et subjekt (forfatter, læser, tilskuer eller voyeur) retter sit blik imod et eller andet og afgrænser dette $\mathrm{i}$ forhold til noget andet, er der tale om repræsentation. Denne découpage og dens enhed med det syn, subjekt etablerer, er »the Organon of Representation« (s.41).

Denne definition elaboreres af Edward Branigan i Point of View in the Cinema(1984), der til Barthes begreber »frame«, »vision« og »object« føjer begreberne »origin «, »time« og »mind «.

Den klassiske objektive indstilling er den ind- stilling, der ikke er knyttet til en af de medvirkendes syn (i perceptionel eller metaforisk forstand).Vi ser f.eks. helten og heltinden møde hinanden i en objektiv indstilling. En sådan indstilling har ikke noget »origin «, den udspringer ikke af noget defineret syn eller punkt - det er så at sige blot noget, som viser sig, selvom alle disse objektive (og subjektive) indstillinger i en afsluttet fortælling eller i en tv-faktaudsendelse under ét kan kaldes for tekstens overordnede synvinkel. Derimod er den subjektive indstilling eller det subjektive flashback den eller de indstillinger, som udspringer af en iscenesat persons syn - her er det et markeret »origin« i fortællingen. Det etableres via en objektiv indstilling, hvor vi ser en person »se« (»vision«) et eller andet, hvorefter dette et eller andet nu ses fra den fiktive persons synsposition. Man kan herefter udlede, om der er sket tilbageblik (tid), der i det mindste forudsætter en særlig mentalitet (hukommelse) og nogle begivenheder (»object«), vi så kan placere rumligt (i forhold til den objektive indstillings rum).

Branigan mener, at alle 7 begreber er nødvendige for at kunne forklare, hvordan filmen etablerer en subjektiv repræsentation inde i en ellers objektiv repræsentation. Hvoraf opstår denne nødvendighed? Branigan svarer ikke specifikt på dette spørgsmål. Svaret ligger implicit i de forudsætninger, han baserer sin semiotiske teori på. For Branigan hænger denne nødvendighed nemlig sammen med den almene forestilling om den audiovisuelle repræsentation: De levende billeders evne til at registrere, hvad der foreligger for kameraet, altså mediets særlige imitative evne. Mediets »realisme« er givet af den afhængighed, der ligger $i$ en slags mekanisk reproduktion af det foreliggende, som så modvejes af den formethed, der omfattes af rammens afgrænsning - nogle objekter er ikke til stede, andre er - og i synsvinkel - fra den position kameraets syn etableres.

Både Branigan og Barthes tager udgangspunkt i en bestemt opfattelse af den fotografiske repræsentation som fundament for de levende billeders repræsentation, en opfattelse, der er formuleret af André Bazin (1951). Det er det fotografiske billedes repræsentaion af det foreliggnde objekt og den automatiserede proces i reproduktionen af det, der var til stede, dengang billedet blev taget - nu lysspor på negativ/positiv - der får Bazin til at hævde, at filmen også skal stræbe efter en realistisk stil. Den ontologiske relation mellem 
billede og objekt - at der er identitet mellem det lysmønster, der skaber billedet og det lysspor, som er forårsaget af objektet - fører til et værdimæssigt krav om en realistisk stil. Men som Noël Carroll (1996) påpeger, er denne repræsentationsopfattelse forkert, fordi man altid kan ændre en smule på det fotografiske billede, så lysmønsteret ændres præcis så meget, at det ikke længere er identisk med det lysmønster, der gælder for objektet. Det vil f.eks. være tilfældet ved ekstreme nær- og fjernoptagelser. Det samme gør sig gældende med automatisme-argumentet. At det fotografiske billede er en reproduktionsproces, som mennesket er herre over, er jo en sandhed med modifikationer. For ét er, at vi som aktive subjekter vælger motiv, vinkel, afstand, sætter lyd osv. Noget andet er, at sådanne valgmuligheder også gør sig gældende for de fleste andre medier.

På trods af sin kritik af Bazin indrømmer Carroll dog, at der er en eller anden form for fremstilling af det, der sættes foran kameralinsen, og som samtidig gør modtageren i stand til at forstå og genkende det repræsenterede. Elaborerer vi yderligere på denne forståelse af visualiteten, kan vi sige, at repræsentationsbegrebet omfatter det aspekt ved de levende billeder, at det, som er repræsenteret, enten ikke er til stede i samme rum eller i samme tid som objektets rum og tid. Ser vi en autentisk optagelse af en begivenhed, f.eks. John Glens triumftog på 5'th Avenue 1962 efter sin rumrejse, så er den forskudt i såvel tid som rum. Det foregik i 60'erne, og vi ser nu de samme begivenheder, ligesom vi sidder et andet sted, end der hvor begivenhederne fandt sted. Ser vi derimod en direkte transmission fra Olympiaden i Sydney, så foregår den samtidigt med vores reception, men er forskudt i rum. I repræsentationsbegrebet ligger med andre ord den kendsgerning, at et objekt (en genstand, en begivenhed) er til stede i en mediedefineret udtrykssubstans i en forskudt tidslig eller rumlig form.

Og går man lidt videre, kan man med den kognitivistiske filmteori sige, at ligegyldigt om objektet foran kameraet er manipuleret, dvs. stillet op i en komposition med en særlig hensigt, og uanset om lyssætningen er realistisk eller ekspressiv, er pointen den samme: Mediets udtrykssubstans skaber et sæt af betingelser, som muliggør en særlig mental læseform, der er meget lig med den måde, vi perciperer virkeligheden på. Som modtagere placeret foran de levende billeder er vi henvist til at læse disse i kraft af de kognitive kapaciteter, vi er udstyret med. Vi processerer de informationer, vi modtager, og anvender de skemata, der »konstruerer« en »realistisk-objektiv« perception.

En helt tredje tilgang til brugen af repræsentationsbegrebet finder man hos Jens Toft, som i Filmsprog, subjekt og samfund (1985) skriver (s. 97):

Som nævnt defineres et cinematografisk repræsentationssystem som en sprogbrugskode og er som sådan lokaliseret »mellem« filmsproget og de filmiske tekstsystemer.

De cinematografiske repræsentationssystemer er historisk specifikke organisationsformer for viden og drift. Dermed mener Toft, at der til bestemte organiseringer af de cinematografiske udtryk er knyttet hhv. ideologi og særlige lyststrukturer. I Toftsk forstand er et cinematografisk repræsentationssystem derfor den særlige måde, hvorpå filmens udtryk (stilsystem) er organiseret med henblik på at fremstille et bestemt indhold. For eksempel er det, vi filmhistorisk benævner »den tyske ekspressionisme«, et cinematografisk repræsentationssystem. Der sker her et valg af særlige udtryksformer (hvoraf nogle er valgt, andre fravalgt blandt en mængde mulige), f.eks. den særlige komposition med skæve linjer, hvor »handlingen« så at sige udspiller sig mellem billedets planer, den særlige lyssætning, det bevægelige kamera osv. Alt i alt en stil, der fremstiller sin historie i situationer mere end i den fortælling, der fremstilles i overgangen mellem situationerne, som det er tilfældet i Hollywoods klassiske fortællestil.

Spørgsmålet er, om repræsentationssystem i Toftsk forstand er noget andet end den repræsentation, vi taler om? Repræsentationssystem er som nævnt en organisering af forskellige udtryksmuligheder, der interpellerer subjektet ideologisk og driftmæssigt; men det er samtidig baseret på den mediespecifikke repræsentation, der kendetegner det audiovisuelle filmmedie. Det undersøger Toft med Metz' Le signifiant imaginaire (Metz 1977, 1984) som den vigtigste inspiration. Det drejer sig om, i hvilken forstand den visuelle perception af det fiktionale filmbillede er driftmæssigt organiseret, $\mathrm{og}$ det hænger netop sammen med filmbilledets nærvær, dets evne til at være spejl for subjektet i biografsædet. Det er så at sige filmbilledets evne til realistisk at »spejle« objektverdenen, der muliggør dets status af narcissistisk spejl for tilskuersubjektet. Hvis ikke filmbilledet har den egenskab, at det 
gengiver det objekt, man stiller foran det, på en sådan måde, at man genkender sig selv i det, ville det ikke kunne skabe den spejlrelation, som både Metz og Toft baserer deres teoridannelse på. Derfor er det også for denne ideologikritiske og psykoanalytiske tilgang til repræsentationsbegrebet en vigtig forudsætning, at filmbilledets »recording « viser os en objektverden på samme måde, som vi perciperer den virkelige verden på. $\mathrm{Og}$ i Tofts begreber er repræsentation først og fremmest gjort til et stilsystems måde at præsentere fiktive fortællinger på. Fokus er dermed flyttet fra det fotografiske billedes ontologiske status til de formelle stilsystemers betydningsdannelse.

Mest radikalt er repræsentationsbegrebet diskuteret af den amerikanske filmteoretiker Noël Carroll. Han siger, at der ikke kun er én form for repræsentation, men altid flere »modes«. At billedet »recorder« det forgangne og altså i almindelighed foretager en registrering af objektet, er én form for repræsentation. Forestiller vi os f.eks. et stillbillede fra filmen Superman (1978) forestillende Supermand, repræsenterer dette billede så Christopher Reeve (der spillede rollen som supermand) eller den fiktive figur Supermand? Og hvordan kan man forestille en fiktiv figur? Andre Bazins opfattelse af billedets repræsentation skaber vanskeligheder, når dette skal forklares. For det er jo Christopher Reeve, der stod foran kameralinsen, da der blev fotograferet, men det er ikke Christopher Reeve, billedet forestiller. Carrolls svar på disse spørgsmål er, at andre »modes of repræsentation « næsten altid er til stede samtidig med selve den registrerende karakter, som et billede har. Billedet af Supermand forestiller som sagt Supermand, men det er også et mere generelt udsagn: dette er en mand (blandt klassen af enheder, vi kan kalde mennesker), og hertil kommer en tredje »mode«, den nominelle repræsentation, som vedrører det forhold, at det er den overordnede brugskontekst, der definerer betydningen i billedet og dermed, hvad billedet refererer til. Den nominelle repræsentation defineres af spillefilmkonteksten, altså det forhold at filmen er produceret for et biograf- eller tv-publikum. Filmen er derfor kommunikationsmæssigt rettet ind efter at gøre sig forståelig for dette publikum. I vores eksempel er Supermand derfor en person, som har visse egenskaber, der gør ham i stand til at handle $\mathrm{i}$ et bestemt univers. Vores forståelse af denne fiktive figur er baseret på den nominelle repræsentation, der så at sige overlejrer de to andre repræsentationsformer og præciserer, hvad der konkret refereres til.

Netop brugssammenhængen eller den institutionaliserede kommunikative kontekst, som jeg har kaldt det (se Højbjerg 2000), er afgørende for billedernes reference. Peter Larsen skrev allerede om dette i artiklen »Billedanalyse« fra 1976, hvor han påpegede, at billedets semantiske flertydighed betyder, at andre tekstlige forhold må udpege den specifikke betydning, der skaber billedets reference.

På grund af det fotografiske billedes flertydighed behøves en anden kontekst end billedet selv til at udpege referencen, og først, når denne kontekst er til stede, kan man sige, at billedet er brugbart. Når det ikke volder os nævneværdige problemer i det daglige at identificere billeders betydning og reference, er det netop, fordi vi omgives af en uendelig række af institutionaliserede kontekster, der udpeger referencen i de billeder, som man uden denne nominelle funktion kun ville kunne udtale sig om i begrænset omfang. I sådanne tilfælde ville man kun kunne tale om billedets »recording « og ind i mellem også om, hvilken klasse af objekter det drejede sig om.

\section{Reprasentation}

Som tidligere beskrevet er det Finnemanns påstand, at det er computerens variable brug af algoritmisk syntaks i sammenhæng med et binært alfabet, der gør det muligt for computeren at indeholde alle andre tidligere medieudtryk. Denne påstand forekommer sandsynlig og velbegrundet. Herudover opererer Finnemann med to repræsentationsbegreber, nemlig et, hvor de forskellige udtryk på computeren er repræsenteret (f.eks. film, tv, ballet, grafik, malerier, landkort), og et andet, hvor alle disse udtryk er repræsenteret i det binære alfabet med den algoritmiske syntaks (som via interfacen kan blive til visuelt genkendelige udtryk på computerens skærm). Det er det, som Finnemann kalder for en skriftteknologisk revolution. Der er imidlertid visse problemer med de to repræsentationsbegreber.

Vi kan se videosekvenser, tv-udsendelser, fotografier osv. repræsenteret på computerskærmen. Som sådanne er de medier, der optræder i et andet medie, og det rejser naturligvis spørgsmålet om, hvorvidt der blot er tale om en helt gennem- 
sigtig fremstilling af originalmediets udtryk, f.eks. en tv udsendelse, eller om der reelt sker en ekstra iscenesættelse af det fremmede medie i computermediet. Men hvordan skal vi forstå originale medieudtryk, som allerede er medierede af andre medier, når de optræde i computermediet?

Når eksempelvis teater eller ballet filmatiseres, sker der ikke en en-til-en-kopi af den foreliggende virkelighed. Forestillingen ses fra en bestemt kameravinkel, og måske klippes indstillinger sammen fra en to-kameraopsætning. Tilskuerpositionen er derfor anderledes, end hvis man sad nede i teatersalen. Der sker med andre ord en »framing«, en indramning af det, som foreligger konkret. Det er i denne Barthske forstand, at filmatiseringen af et teaterdrama er en repræsentation af en anden repræsentation. Pointen her er, at der i teaterets fremstillingesform, i den stil, hvorigennem det udtrykkes, er indbygget en række receptionelle »framinger«. For eksempel er den talte dia$\log$ altid fremført på en sådan måde, at både forreste og bageste række kan høre den. Den høje stemmeføring er gennemført som netop en del af teaterets repræsentation, som så fordobler sig i den filmiske repræsentation.

Når vi ser teater på computeren, er det filmatiseret og her repræsenteret i sin oprindelige repræsentation, men samtidigt re-repræsenteret af en række filmiske repræsentationsforhold. Hertil kommer, at der i hovedreglen også er nogle omgivende forhold på computeren, der muliggør den interaktive styring med musen, og som gør det muligt at se, afbryde, spole fremad osv. Disse forhold betyder, at computeren er synlig i selve mediet, hvilket betyder, at computeren som sin egen repræsentation altid er til stede. I modsætning til f.eks. videobilledet på en tv-skærm, hvor selve styringen er udenfor den visuelle repræsentation, er den på computeren som regel inde i billedfeltet.

Medhensyn tildetandetrepræsentationsbegreb, som Finnemann betjener sig af, er der faktisk flere problemer, end det er tilfældet med det første. Det, vi taler om, når det gælder repræsentation i det førstnævnte tilfælde, er, hvordan eksempelvis filmbilledet er repræsenteret på computeren. At de samme levende billeder så også er repræsenteret i et skriftsprog af binær-algoritmisk karakter, er i virkeligheden underordnet - det er ikke en skriftteknologisk erobring af billedkulturen. Det er underordnet i samme forstand, som det periodiske grundsystem med sin atomare op- deling repræsenterer den fysiske verden, vi omgives af. Det er uinteressant, at et hus f.eks. består af atomer i en bestemt molekylær struktur. Vores visuelle oplevelse og brug af huset er ikke afhængig af dette. Om huset er lavet af brændte lersten eller beton, er ikke underordnet, når man ser på dets funktion som bolig, men at det er de samme atomer, der indgår i betonen og lerstenene, er derimod helt ligegyldigt for denne funktion. Husets repræsentation i det periodiske system som en række definerede atomer er en helt anden type af sandhed, end den oplevelse vi har af huset og dets brug. De binære alfabet og den algoritmiske syntaks er en betingelse for levende billeders repræsentation på skærmen, men som sådan er de ikke identiske med deres fremtræden, og i forhold til brugen af billederne er de helt irrelevante. Oplevelsen af billeder og andre medierepræsentationer på skærmen kan ikke reduceres eller forklares med et binært alfabet og en algoritmisk syntaks. Billederne ændrer ikke fundamentalt karakter på grund af dette. Det vil stadigvæk være receptionelle brugssammenhænge, der definerer betydningen i og oplevelsen af billedmedierne på en computerskærm.

Med hensyn til den varians, der er mellem computerens vidensindhold og det binære alfabet og den algoritmiske syntaks, er det derimod en pointe, at man lettere end tidligere kan manipulere med billederne. Alle de manipulationsudstryk, der kan benyttes med en computers arsenal af muligheder, er i det store og hele set tidligere i de analoge medier. Det binære alfabet og den algoritmiske syntaks har blot gjort det lettere og hurtigere.

\section{Flerreprasentationen}

Det interessante i denne problemstilling er imidlertid flerrepræsentationen. Hvorfor ses den som et næsten uundgåeligt træk ved computeren? Flerrepræsentation er ikke noget helt nyt fænomen, men er set i mange forskellige medier tidligere. Lad os derfor, inden vi prøver at besvare det ovenstående spørgsmål, kaste et blik på forskellige typer af flerrepræsentationer.

I filmen har man til tider set en telefonsamtale visualiseret $\mathrm{i}$ split screen: den ene person talte $\mathrm{i}$ venstre side af billedet, mens den anden talte i højre billedside. Samme tid, men forskelligt rum karakteriserede denne flerrepræsentation i samme 
medie. I reklamebilleder i aviser og ugeblade er det normen, at man f.eks. bruger et fotografi med tekster henover billedet, eventuelt med et billede af det reklamerede produkt ovenpå det fotografiske billede, således at forskellige mediefremstillinger er »monteret« i en samlet fremstilling. Det er den slags flerrepræsentationelle kommunikationsformer, vi er vant til at se, fordi de er institutionaliseret kommunikationelt. Den slags fremstillingsformer er udtryk for en fasttømret brug af forskellige medieudtryk, der så at sige er blevet til sin egen veldefinerede genre. Som modtagere ved vi, hvordan de skal begribes.

Flerrepræsentationer er normen i computermediet. Der er altid en central arbejdsflade - et symbolsk stykke papir og symbolske redskaber, et billede, en digital video - som er lagt oven på eller omgivet af andre repræsentationsformer. For eksempel er papiret og blyanten altid indrammet af nogle redskabskolonner eller menuer, og derudover findes der links til computerens styresystem et eller andet sted i den visuelt synlige flade, så det er muligt for brugeren at komme et andet sted hen, mens programmet med skrivepapiret er åbent. Spiller vi en digital video i QuickTime-formatet, ses den indrammet af en særlig skærm, nogle gange med tidsangivelse og med play-, stop- og rewindknapper. Importeres videoen i f.eks. Director 8.0, ser vi den på en Stage, fremstående helt uden QuickTimes ramme, men nu er den er omgivet af andre visuelle baggrunde (eller blot neutral hvid), som i sig selv ikke fylder hele skærmen, hvor så skrivebordet ses som baggrund med menubjælke, skraldespand osv.

Mange cd-rommer benytter sig af flerrerpæsentationer i deres fremstilling. Som regel er den »node« (det selvstændige tekstfragment, hvorfra man linker til andre tekstfragmenter i hyperteksten), man iagttager, knyttet til alle andre nodes fra samme cd-rom. I f.eks. cd-rommen Far fra 1999 er de centrale informationer og videoklip lagt i højre side af computerens billedflade, mens venstre side er optaget af knapper og links tilbage til hovedmenuen. Det hele er monteret på en grøn baggrund, der går igen i alle cd-rommens »nodes«. Ofte er der under billedet eller videoen en ledsagende tekst, så hele den visuelle flade er en montage af tekster, der imidlertid i kraft af den stilistiske kontinuitet (Højbjerg 2001) markerer sin tekstenhed.

Også computerspil har indbygget menubjælker, der er betjenbare, samtidig med at man ved hjælp af joystick eller piletaster tonser løs. I Microsofts lancering af Windows 95 blev multitasking, altså dette at flere programmer kunne være åbne samtidig, et af kampagnens mest fremtrædende slagord. Det pointerer imidlertid også flermedialiteten på computerens brugerflade, der i nogle sammenhænge (f.eks. visse hjemmesider) kan antage helt uoverskuelige former. I enkelte situationer kan man låse computerens skærm fast i en enkelt medieflade - f.eks. i visse computerspil efter at brugeren $\mathrm{i}$ andre medieformer (tekster og grafik) har foretaget en række »settings«. Men betragtet under ét er computerens visuelle brugerflade præget af flerrepræsentation.

Inden vi går videre, kan vi tage et udblik til de samtidige medier og deres flerrepræsentationelle karakter, f.eks. tv-mediet. Hvad bruges flerrepræsentationaliteten til?

\section{Nogle eksempler fra tv}

To billeder i et, eller et ovenpå et andet, betyder konkret, at modtageren udsættes for et valg. Modtageren kan dårligt læse begge billeder samtidigt, men skal læse det ene først og dernæst det andet. Det giver en tidslig forskydning i det samtidige eller en simpel opmærksomhedsforskydning, hvorved det ene billede fravælges. For eksempel fortæller Bubber i Snurre Snups Søndagsmagasin (TV2) om popgruppen fuice, mens man i venstre hjørne ser en video med gruppen. Ser man på videoen, forsvinder de fleste af informationerne i hovedbilledet fra opmærksomheden, og hører man derimod efter, hvad Bubber siger, forbliver billedet kun en baggrund for forgrunden.

De mange »tekster« samtidigt er imidlertid ikke kun et spørgsmål om informationsnødvendighed, men også en stil, en æstetik. Ofte kan repræsentationer, f.eks. en QuickTime-movie, der åbnes oven på skrivebordet eller på Directors platform, flyttes rundt på skærmen, som man har lyst til, og derfor kan man selv skabe sin egen æstetik fra rod til orden og balance. Men mange færdige computerprogrammer, hjemmesider, cd-rommer og computerspil er sat op på en måde, der sikrer en homogen visuel stil uden for brugerens kontrol.

Flerrepræsentationerne er skabt efter et klassisk stilistisk ideal om skønhed og balance (jvf. Arnheims diskussion af det æstetiske (Arnheim 
1959)), men er samtidig en klar ekstern stilmarkering. Andre medier har taget denne dobbeltrepræsenterende stil til sig i en slags æstetisk interface. Tv-reklamer, biografreklamer, tv-udsendelser har stilistisk lagt sig i forlængelse af computermediet (Højbjerg 2000 a, 2000 b). I sportsudsendelser, talkshows,interviewudsendelser, reklamefilm, previews, shows, quizserier (f.eks. Lykkehjulet) finder man flerrepræsentationer i en eller anden form. I sportsudsendelser ser man f.eks. en bjælke i bunden af billedet med billeder eller tekster omhandlende noget andet end det, der ses og tales om i selve billedet. To eksempler: en preview for ishockeylandskampen mellem Danmark og Holland (2000) og den ugentlige interviewudsendelsen Centrum (2000) med Claus Hagen Petersen som vært.

I ishockeylandskamp-previewen er det forskellen i tidslig og synsvinkelmæssig variation, der gør forskellene. Det basale baggrundsbillede er en blanding levende billeder i sort-hvid og farve fra en ishockeykamp - det ses let sløret. Oven på dette baggrundsbillede skyder sig rødkantede farveindstillinger i slowmotion ind i den midterste del forestillende forskellige situationer fra en ishockeylandskamp. Der er i alt 6 af sådanne indstillinger. Den første bevæger sig ind på baggrundsbilledet og fryser, hvorefter den næste begynder at bevæge sig ind i billedrammen og lægger sig ovenpå den første indstilling. Der er dog ikke mere end to indrammede levende billeder ad gangen, som er lagt ovenpå hinanden og placeret ovenpå baggrunden. Det hele varer i alt 21 sekunder.

I Branigans forstand er det forskellige objekter (fra samme begivenhed), vi ser: en skøjtende ishockeyspiller, en dommer, en målmand. Det er det samme rum $i$ alle 6 indstillinger, men de er tidsligt forskudt. Den første tid er baggrundsbilledernes tid, og ovenpå denne er lagt to andre indstillinger med hver sin tid (de er fra forskellige tidsperioder af en tidligere ishockeykamp). Der er altså tre tidslige repræsentationer i tvs samtidige udsigelsestid. Den klassiske film- og tv-repræsentation er her ændret: de tre tider er forskellige (og dermed også tre samtidige forskellige synsvinkler), hvorimod rummet og objektet (og »vision« - synsakten) er det samme.

I interviewprogrammet Centrum (TV2) ser vi Claus Hagen Petersen som interviewer og en prominent person (oftest valgt i et tidsaktuelt perspektiv) som interviewoffer. Billedfladen er inddelt af en ornamenteret sort bjælke, der splitter billedet i tre enkeltindstillinger. Den største indstilling ligger øverst i billedet, og her ses Hagen Petersen og hans interviewoffer, og det samme ses $i$ to andre mindre indstillinger $\mathrm{i}$ bunden af billedet. De to andre indstillinger har imidlertid en ændret synsvinkel, men det, som foregår i alle tre indstillinger, er samtidigt. Det er samme rum, samme tid, samme objekt - kun synsvinkelen er forskellig. Og selvom der også her er tale om en anden repræsentation end den klassiske i levende billeder, er der - ligesom i tilfældet med previewet for ishockeylandskampen mellem Holland og Danmark - ikke tvivl om, at denne flerrepræsentation ikke nævneværdigt ændrer på selve formidlingen af informationer.

I begge de nævnte tilfælde er stilen mere ornamentel end funktionel. Den ekstra-repræsentationelle stil har ikke et informerende formål. Vi får ikke et større overblik eller mere information om f.eks. kropsproget, fordi der er flere indstillinger i samme billedramme i Hagen Petersen-interviewet. Opsplitningen i tre indstillinger giver ingen ekstra informationer til interviewet, selvom man formelt kan tale om, at tre forskellige visuelle synsvinkler på samme begivenheder altid giver modtageren flere informationer. Når man ser den interviewede person i hovedindstillingen argumentere, og i en af underindstillingerne samtidig ser vedkommende i profil argumentere, får vi som modtagere ikke flere relevante informationer, som giver dybde eller perspektiv. De ekstra informationer, vi får i forhold til hovedindstillingen, ville kun være relevante, hvis vi kunne se betydningsbærende dele af billedet, som ellers ville være uden for synsvinkel i de andre indstillinger, men det er de ikke. Flerrepræsentationen i tv er derfor udtryk for en meget redundant stil. Denne windowsæstetik, som jeg har kaldt det (Højbjerg 200 b), kan findes i mange andre udsendelser, reklamefilm og musikvideoer mv.

Som visuel stil er windowsæstetikken udtryk for en refleksion af det multimedieprægede samfund - et samfund, som for 12 år siden havde en landsdækkende tv-kanal uden reklamer, og hvis mediemæssige uskyld i dag er radikalt ændret, ikke mindst fordi computeren og internettet har givet os adgang til andre og langt mindre monopolstyrende informationer, end vi før har været vant til. 


\section{Flerreprasentationer i computeren}

I tv, film, reklamer og ugeblade er flerrepræsentation blevet en visuel stil, der i meget redundant form bærer samtidens selvforståelse. Men det gælder ikke for computeren. Her er det ikke kun en stil, det er også en nødvendighed, i og med at computeren er en platform for alle andre medieudtryk. De forskellige medier optræder på computerens skærm uden for deres oprindelige kommunikative kontekst, og derfor er det nødvendigt for brugeren at få angivet de kommunikative betingelser for den aktuelle repræsentation. I deres respektive traditionelle institutionaliserede kommunikationssammenhænge fremstår de forskellige medieudtryk med en selvfølgelighed, som forsvinder, når mediet repræsenteres i et andet medie. En film eller en tv-udsendelse om f.eks. en maleriudstilling kræver en hel del verbal forankring, før modtageren ved, hvilke forventninger man kan have til det, som skal ses, og hvordan det skal forstås. Når den institutionaliserede kommunikationssammenhæng er væk, skal den genskabes, og det sker på computeren i bl.a. flerrepræsentationen: Man ser et medieudtryk oven på et andet, og som regel er computerens skrivebord nedenunder: Den egentlige baggrund er computeren selv, der efterhånden symbolsk er blevet tekstualiseret med skrivebordet. Modtageren må så kognitivt søge efter den af repræsentationerne, der udgør indgangen eller for-tekstningen til de andre tilstedeværende medieudtryk, for at kunne få betydning ud af det repræsenterede.

Det er givet, at nogle spil, hjemmesider og forskellige programmer også er stiliseret som flerrepræsentationer, men set $i$ et lidt større perspektiv er flerrepræsentationerne en kommunikativ nødvendighed på computerens skærm, fordi brugsfunktionerne og de tekstuelle udtryk er så mange. At det så er blevet til en markant visuel stil i diverse tv-udsendelser (windowsæstetik), er blot udtryk for de tidslige dynamikker, der hersker mellem samtidige medieudtryk, men det skyldes også, at de fleste moderne medier i dag baserer deres produktionsproces på computerens som redskab.

\section{Litteratur}

Arnheim, Rudolf (1974 (1959)): Art and Visual Perception. Los Angeles.University of California Press.

Barthes, Roland: (1974) »Diderot, Brecht, Eisenstein", Screen vol 15. nr. 2. Oxford.

Bazin, Andre (1961): Qu'est-ce que le cinema. Paris. Editions du cerf.

Bondebjerg, Ib (2000): Moving Images, Culture and the Mind. Luton Press.

Branigan, Edward (1984): Point of View in the Cinema. Berlin. Mouton Publishers.

Carroll, Noël: (1996) Theorizing the Moving Image. Melbourne. Cambridge University Press.

Finnemann, Niels Ole (1998): »Computeren Et medie for en ny skriftteknologisk revolution« in: Jens. F. Jensen (red) Multimedier, Hypermedier, Interaktive Medier. Aalborg.

Finnemann, Niels Ole (1994): Tanke, Sprog og Maskine. København. Akademisk.

Gombrich (1992, 1959): Art and Illusion - The Psychology of Representation. London. Phaidon.

Højbjerg, Lennard (1997): »Stil og repræsentation«. Sekvens 1997. København.

Højbjerg, Lennard (1998): »Stilens betydning«. Kosmorama 221.

Højbjerg, Lennard (2000 a): »Den nye tv-stil«. MedieKultur 30.

Højbjerg, Lennard (2000 b): »A New Televison Style«. in: Bondebjerg 2000.

Højbjerg, Lennard (2001): »Stilistisk kontinuitet - et nødvendigt træk ved multimediet« www.design.emu.dk/artik/artikf.htm.

Larsen, Peter (1976): »Billedanalyse«, in Olivarius, Rasmussen og Rugholm: Massekommunikation. Dansklærerforeningen.

Mayer, Paul (1997): Typologies for the Analysis of Computer Media. Convergens 3. Luton.

Metz, Christian (1977): Le signifiant imaginaire. Paris. du Seuil.

Toft, Jens (1985): Filmsprog, subjekt og samfund. Sekvens 1985. København

Willats, John (1997): Art and Representation. Princeton. Princeton University Press.

Lennard Højbjerg er lektor ved Institut for Filmog Medievidenskab, Københavns Universitet. 